Article

\title{
Photovoltaic Design Integration at Battery Park City, New York
}

\section{Simone Medio}

School of Architecture, University of Lincoln, Brayford Pool, Lincoln, LN6 7TS, UK; E-Mail: smedio@lincoln.ac.uk; Tel.: +44-1522-837181; Fax: +44-1522-886041

Received: 29 November 2012; in revised form: 16 February 2013 / Accepted: 18 February 2013 / Published: 29 April 2013

\begin{abstract}
This paper is a study of the photovoltaic (PV) systems in the buildings' design of the Battery Park City (BPC) residential development, in New York. The BPC development is the first in the US to mandate, through the 2000 Battery Park City Authority (BPCA) guidelines, the use of $\mathrm{PV}$ as a renewable energy generation system in its individual buildings. The scope of this study is to show how PV is integrated in the BPC buildings' design process, and what can be learned for future PV applications. The study draws directly from the design decision making sources, investigating on the concerns and suggestions of the BPCA director of sustainability and the BPC architects and PV installers. It attempts to contrast a theoretical approach that sees PV as a technology to domesticate in architecture and bring, through grounded research, PV industry closer to the architectural design process. The findings of the study suggest that while stringent environmental mandates help, in the short term, to kick-start the use of PV systems in buildings, it is the recognition of the PV's primary role as energy provider, its assimilation in the building industry, and its use in a less confining building program that allows for its evolution in architecture.
\end{abstract}

Keywords: PV and design process; PV and building integration; role of PV in architecture; PV innovation

\section{Introduction}

Photovoltaic (PV) cells transform the visible spectrum of solar radiation (photons) into electrical energy. The greater the efficiency of the PV cell, the larger the PV surface area exposed, and the better the PV's position with respect to the sun, the greater the total electrical output produced. It is important to remember that initial use and testing of PV cells occurred in outer space. In 1958, PV cells were installed in the satellite Vanguard to generate energy to power its radio transmitters. The event was 
significant because it demonstrated the original scope and potential of PV: to effectively generate self-sufficient energy from the sun. This machine-like function and high-tech aesthetic of PV remains fundamentally unchanged and is arguably what challenges architects when PV systems are to be integrated in a building's design. The integration of PV in architecture, however, can also potentially provide an important supply of electricity for a building's energy demand and significantly contribute to the reduction of carbon emissions. The application of PV systems in the Battery Park City (BPC) buildings represents a challenge that architects face globally when presented with PV technology; that is, to make PV perform and assimilate it as constituent parts of the design process.

This paper explores how PV systems are integrated in the design process of the BPC buildings. The scope of this paper is to show what can be learned from the BPC experience for future PV application in architecture. The paper begins with a review of PV in architecture. It then gives a background of the BPC development. The main body of the paper discusses the emerging themes stemming from the architect's integration of PV in the BPC buildings' designs. Finally, the paper draws conclusions on the integration of PV technology in the architectural design process.

\section{Research Method}

The source material of this study originates from on-site video interviews carried out during the construction process of the Battery Park City development in the periods 18-26 June and 14-17 November, 2007, and the period 27 September to 11 October, 2009, with the Battery Park City Authority (BPCA) director of sustainability, the architects in charge of the buildings concerned, and the BPC PV installer. The raw interview data is transcribed and subjected to content analysis to show emerging themes in the integration of PV in the building's design. The content of each theme is interpreted through observation and literature review. Conclusions are then drawn from the findings.

\section{PV in Architecture-A Review}

Literature on the application of PV in architecture is easily accessible and rapidly growing. This is particularly the case for practical manuals and handbooks that provide architects with design guidelines and case studies for integrating PV in their projects [1-5]. However, for an updated view of the synergy between solar energy, PV industry and architecture, and a better understanding of the forces in the implementation of PV in architectural design, we must refer to the International Energy Agency Photovoltaic Power System (IEA-PVPS) annual reports [6] and program surveys [7].

Established in 1993, the mission of the IEA-PVPS program is to accelerate and promote the development and deployment of PV solar energy through information dissemination and a set of scheduled tasks. The program's premise is that of PV as a sustainable renewable energy source that can significantly contribute to the reduction of carbon emissions and world dependency on fossil fuels. Central issues relevant to the introduction of PV in buildings, accountable for more than $40 \%$ of the world's energy demands are PV economy, government incentives, and technological innovation. In support of the advantages of integrating PV in buildings we find studies, from both IEA-PVPS program and independent sources, which focus on the PV's economic, environmental, and architectural added value [8-11]. 
Within the IEA-PVPS program tasks, Task7 [12,13] and Task $10[14,15]$, are particular to the implementation of PV in the built environment. More specifically, the goal of Task 7 is to enhance PV's architectural and technical quality and its economic viability in the built environment, as well as removing non-technical barriers (such as administrative and market related), while that of Task 10 to enhance wide-scale, solution-oriented photovoltaic power production application in the urban environment. However, the issue of PV architectural quality, which according to the author of this paper is at the heart of PV integration in the architectural design process, is treated only as a subtask of Task 7 (subtask 1).

Subtask 1 is specifically aimed at providing architects with a set of criteria for successfully integrating PV in architecture (design criteria for good quality PV-projects), with guidelines on how PV can be incorporated in the building design process and a database of notable PV applications. While recognizing the difficulty for PV technology to be fully incorporated in the design process, Kaan and Reijenga [16] underline the value of Task 7 architectural criteria as a starting point for architects to orient themselves when integrating PV in their designs. The argument is that because PV is not an indispensable material in architecture it is seen by architects as an add-on element and in need of an organized set of criteria. The view of PV as a separate added element of architecture is evident in more recent publications [17] and, as will be shown, reinforced by those directly involved in the design decision making process.

Arguably, the prevailing approach to PV's integration in architecture is top-down. It starts from the PV industry, and the powerful arguments that support its proliferation, and pushes towards its acceptance and incorporation in architecture. By contrast, the author of this paper would like to stress the importance of the contributions that go from the design process experience towards the PV industry. In this direction, and non-withstanding the specificity of its location, the BPC development offers a unique opportunity of investigation. At BPC, within a framework of time, building program and site, architects, PV installers, and real estate developers, are called to respond to the introduction of PV as a mandatory requirement. This results in diverse design approaches and in emerging themes that are perhaps a call from the world of architectural design to that of the PV industry.

\section{The Battery Park City Development}

The BPC development (see Figure 1) is located on the Southwest tip of Manhattan Island. It sits on a reclaimed area of approx. 92 acres, and measures one mile end to end, all on the West of the West Side highway.

The idea of the BPC development starts in the mid sixties, following the dismantling of the shipping industry and the progressive decay of the piers jutting out onto the river. Susan Kaplan, Director of Sustainability at the BPCA explains how this large dysfunctional area on the waterfront was seen by the then ex-governor of New York, Nelson A. Rockefeller, as an opportunity to have full jurisdiction over buildable areas and, through the strategy of reclaimed land, start an entire new city jutting out from Manhattan Island [18]. The development of BPC goes through two distinct phases that are visually experienced with a visit to the site. The first goes from the mid-sixties to the new master plan of 1979. It is defined by several master plans that result in closed communities such as the Gateway, which shows exclusion to street life and nature. The second phase stems from the 1979 master plan. 
This phase begins to include environmental considerations, primarily at an urban design scale, and can be considered the reference driver for the rest of the BPC development.

Figure 1. (a) Plan of the Battery Park City (BPC) development. Photographs of the site looking: (b) Southeast and (c) Northeast [19].

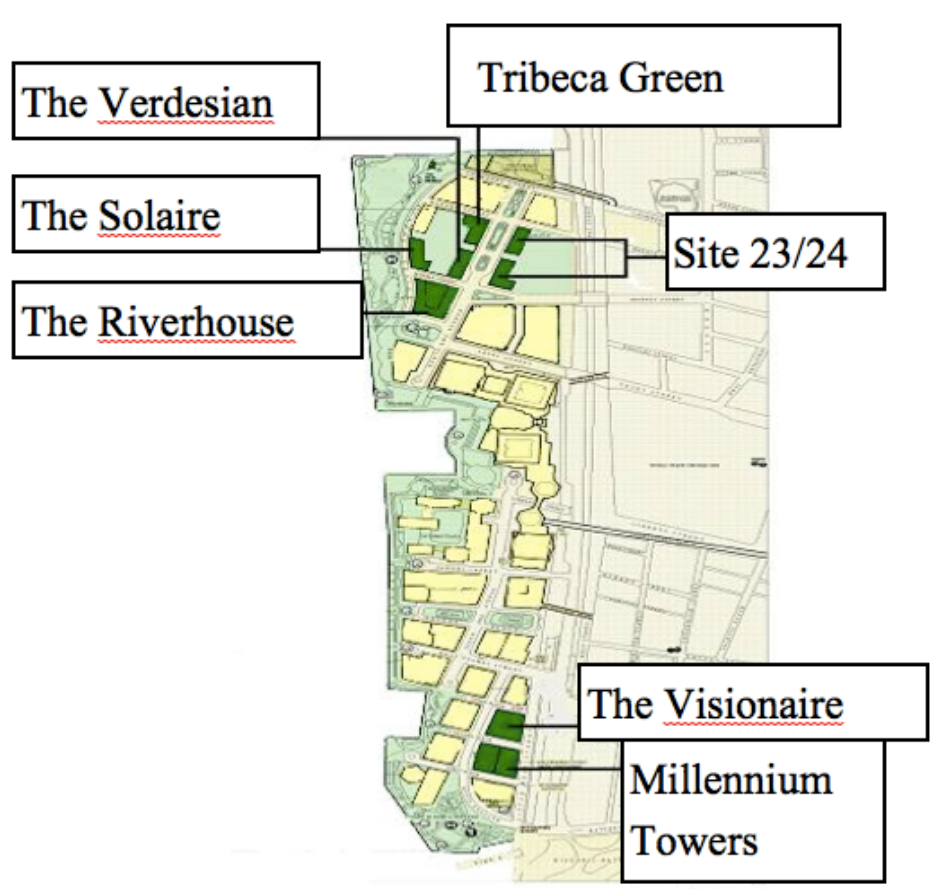

(a)

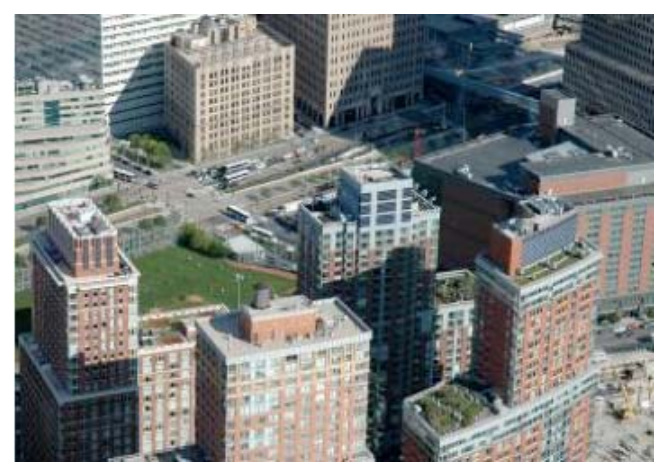

(b)

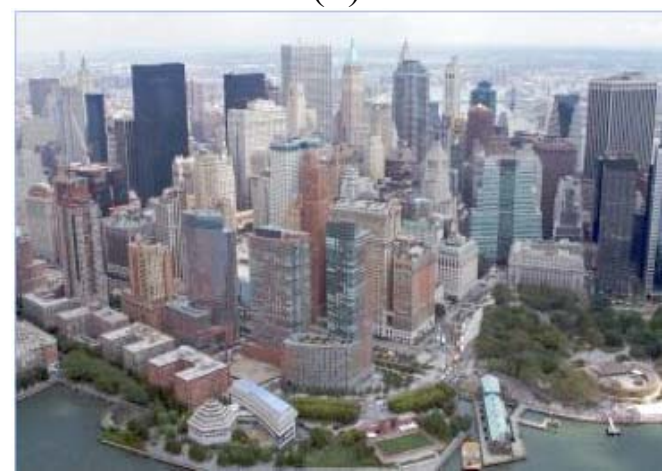

(c)

In 2000, the BPCA establishes the Hugh L. Carey Battery Park City Authority Residential Environmental Guidelines [20]. The formulation of the guidelines is coeval to the Leadership in Energy and Environmental Design (LEED) Green Building Rating System [21]. It distinguishes itself from LEED, however, by setting mandates, rather then options, with stringent requirements for the provision of renewable energy and green power sources. The guidelines mandates that renewable energy sources be incorporated in the BPC building's design to initially provide $5 \%$ of the base energy load of each building; that is: the load of the buildings' non-tenanted spaces. Several studies are conducted to explore the different renewable energy options, including wind and biomass. The application of PV systems, however, quickly appears to the developers as the most tested and economic option, and as such it is adopted in the BPC buildings.

The BPC buildings under investigation, completed between 2003 and 2011, represent a test case in PV application. The details of these buildings are shown below, in Table 1. All the buildings follow tight zoning and geometric constraints on massing, orientation, and envelope directives (i.e., the façade's ratio of opaque to transparent). 
Table 1. Battery Park City (BPC) buildings under investigation.

\begin{tabular}{ccccc}
\hline Name of building & $\begin{array}{c}\text { Design } \\
\text { (start) }\end{array}$ & $\begin{array}{c}\text { Construction } \\
\text { (completion) }\end{array}$ & Location and use of PV & Design architect \\
\hline The Solaire & 2000 & 2003 & $\begin{array}{c}\text { West façade BIPV and } \\
\text { bulkhead*(South and West facing } \\
\text { walls). Entrance canopy (West) }\end{array}$ & $\begin{array}{c}\text { Pelli Clarke Pelli } \\
\text { Architects }\end{array}$ \\
\hline Tribeca Green & 2000 & 2005 & $\begin{array}{c}\text { Bulkhead (East, West and South } \\
\text { facing walls) }\end{array}$ & $\begin{array}{c}\text { Robert A.M. Stern } \\
\text { Architects }\end{array}$ \\
\hline The Verdesian & 2003 & 2006 & $\begin{array}{c}\text { Bulkhead (primarily East and West } \\
\text { facing walls) }\end{array}$ & $\begin{array}{c}\text { Pelli Clarke Pelli } \\
\text { Architects }\end{array}$ \\
\hline Millenium Tower & 2004 & 2007 & Bulkhead (West facing wall) & Handel Architects \\
\hline The Riverhouse & 2004 & 2008 & $\begin{array}{c}\text { PV tracking array at rooftop level } \\
\text { (East, West and South racks) }\end{array}$ & $\begin{array}{c}\text { Ennead and Ismael } \\
\text { Leyva Architects }\end{array}$ \\
\hline The Visionaire & 2005 & 2008 & $\begin{array}{c}\text { West and East façade BIPV } \\
\text { Architects }\end{array}$ & $\begin{array}{c}\text { Pelli Clarke Pelli } \\
\text { Site 23 and Site 24 }\end{array}$ \\
\hline 2006 & 2011 & $\begin{array}{c}\text { PV trellises at lower rooftops and on } \\
\text { bulkheads (top and South facing) of } \\
\text { both buildings }\end{array}$ & EE\&K Architects \\
\hline
\end{tabular}

* Bulkhead: structure on the roof housing mechanical systems and other installations.

\section{Emerging Themes}

The emerging themes from the interviews are categorized in four sections, namely: The "carrot and stick" (discusses the effects of mandating PV systems in the BPC development); PV and building integration (discusses the architect's different approaches to PV integration in the design process); PV industry and design process (discusses the difficult relationship between PV industry and the design process); Green visible (brings out the PV overall prevailing function at BPC, comparing the short term symbolic function of PV with its potential long term goal).

\subsection{The "Carrot and Stick"}

Residential development is an exceedingly money conscious sector of the building industry. Newly built residential buildings must generate a certain pre-calculated return, and anything outside of a tested financial program is seen with scepticism and as a risk. Kaplan, states that having mandated the use of PV as renewable generation system through the BPCA residential guidelines has fostered the development of the PV industry in the residential sector [22]. According to Anthony Pereira [23], president and CEO of AltPower, the BPC PV installer, "the reality is that if you did not use the stick, no one would apply the technology, no matter what the incentive. The stick had to happen for it to happen". For the scope of this study, the question is: what effect did the mandatory inclusion of PV have on the BPC architects and developers?

\subsubsection{The Stick}

From the interviews carried out on the buildings under investigation, the architect's general consensus is that, were PV systems not required through regulation, they would not have been 
considered in the building's design. David Hess, project manager of the Solaire (see Figures 2 and 3) and the Verdesian (see Figure 4) buildings goes as far as stating that no one in the design team would have, of their own choice, considered PV, nor indeed any on-site renewable energy source, as an option to promote green design [24]. Overall, the BPC architects welcomed the PV challenge, but saw it more as part of a program to carry through, rather than a design challenge [24-27]. There are multiple reasons that perhaps explain this sentiment. Firstly, the requirement for the PV to provide 5\% of the base building load was seen as minimal and inconsistent for a full engagement of PV into a comprehensive design project. Secondly, overshadowing studies showed that solar access was limited to specific fronts of each building, limiting the architect's design options in terms of PV location and positioning. Thirdly, the building's fixed massing, orientation, and envelope requirements prevented any real spatial contribution of the PV to the building's form. Under these terms, it could be assumed that PV was not considered by the architects on their own accord because it hindered the very nature of the architectural design process: at the design conceptual phase, there was limited scope for PV becoming a participatory element of the design, and PV systems tended to be considered as an add-on element. From a developer's perspective, independently of economic reasons, PV represented a risk. Real estate developers tend to offer buildings that are as neutral as possible to increase the range of potential clients, and there was no precedence to show how NYC clients would respond to a PV clad building.

Figure 2. The Solaire's West façade, seen from the pathway [19].

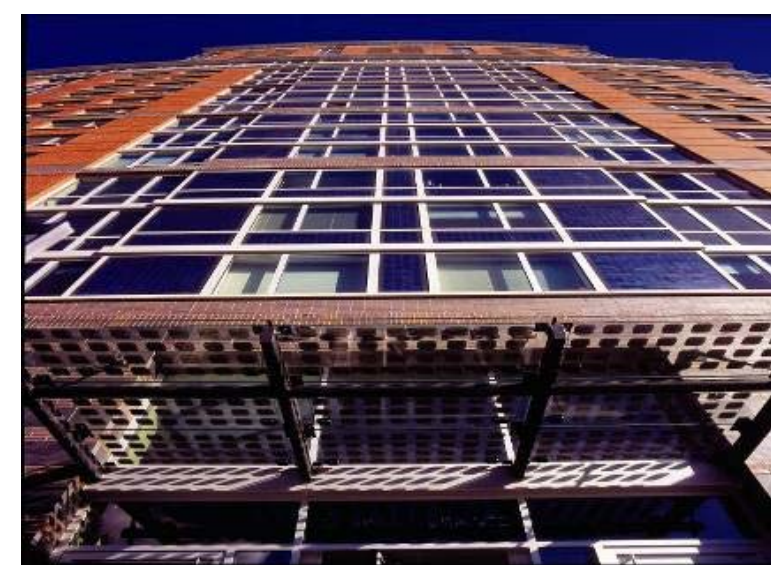

Figure 3. The Solaire's bulkhead [28].

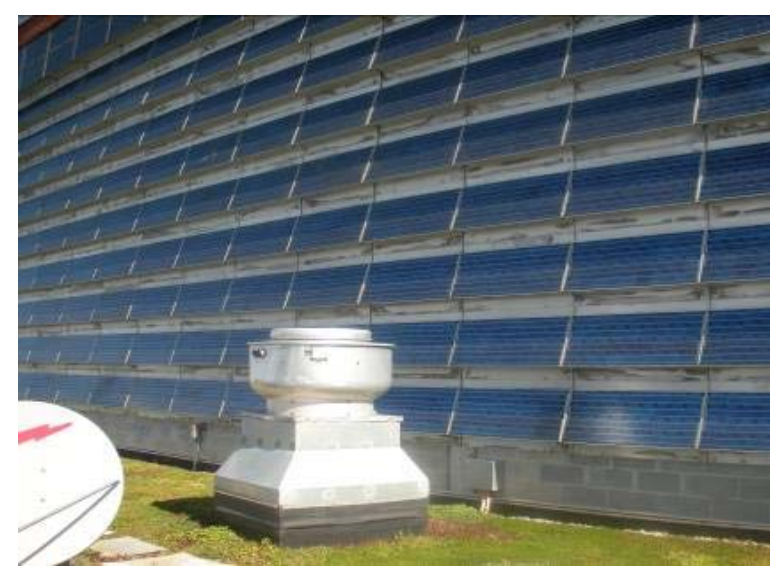


Figure 4. The Verdesian's bulkhead [28].

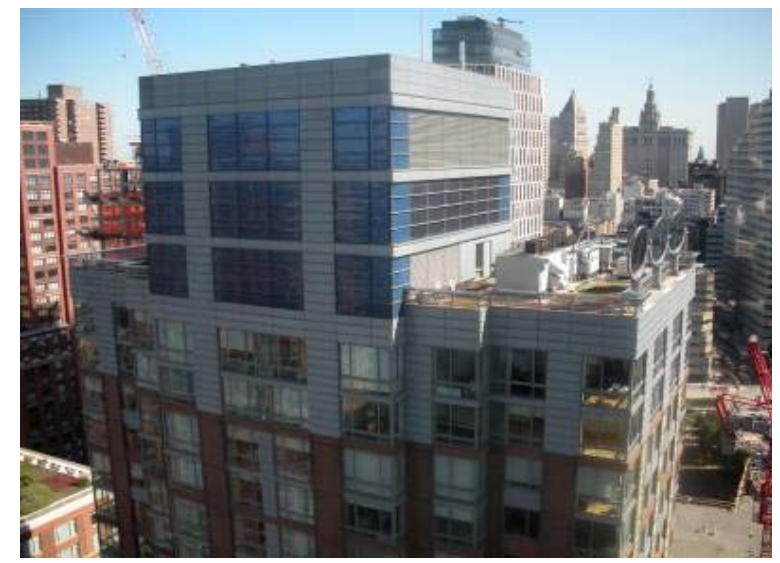

\subsubsection{The Carrot}

It is suggested, however, that it is the very challenges posed by the introduction of PV in the city and the stringent building and environmental guidelines set by the BPCA that has triggered a set of attractive advantages for architects and developers. To begin with, architects were given the opportunity to show, in a highly visible way, the environmental commitment of their practice. BPC has also shown to be an incubator for the use of PV in the city, drawing architects and developers to use $\mathrm{PV}$ in their future projects and engage in the use of PV systems with more confidence. An example is the Helena building in New York, by Fox and Fowle architects, completed in 2005. As PV installer of the Helena, Anthony Pereira [23] states that the decision to include PV in the building's design agenda was fostered by the physical evidence provided by the BPC buildings, bringing forth confidence to the PV initiative. Likewise, the Albanese Developing Corporation, developer of the Solaire, the Verdesian, and the Visionaire has, since their experience at BPC, started to incorporate green buildings strategies as a norm, with the inclusion of PV in most of their projects. Most importantly, the BPC development has triggered the activation of PV government financial support and tax breaks incentives, making the inclusion of PV in buildings' more attractive to clients, architects, and developers, expanding the use of PV in architecture and pushing for innovative solutions.

\subsection{PV and Building Integration}

The definition of a building integrated PV system (BIPV) is that of an energy generating PV surface that also takes on one or more of the functions of the building envelope components. Such functions could be, for example, insulation, rain screen, or a shading device. At best, a PV assembly can serve, besides the energy requirements of a building, many architectural functions combined, offsetting the total cost of a building construction. A full integration of PV in buildings is arguably, however, one where PV is assimilated in the design process and becomes a constituent part of a building's resolution. The BPC architect's address this issue in different ways. In doing so, they show evidence of a split in the PV's potential role as efficient energy provider, building component, and aesthetic complement. Shown below is an exposition of the buildings considered in this study. 


\subsubsection{The Solaire}

The Solaire (see Figures 2 and 3) is the second building in New York City to integrate PV systems (the first is 4 Times Square, located in mid-town Manhattan, about six kilometres north of Battery Park City). The Solaire's project manager describes how sunlight geometry simulation studies showed the Solaire's PV effective surfaces limited to the building's West façade, overlooking the Hudson River, and to the building's bulkhead [24]. In these two zones, the design approach to PV integration is notably different.

On the West façade, the custom-made PV panels are designed as building cladding. In energy terms they benefit from the afternoon sun and its reflections bouncing off the river. Their prevailing function, however, verges towards an aesthetics tour de force, with the unprecedented challenge of relating the building's PV façade to the public at pedestrian level. The PV systems in the Solaire's bulkhead are, by contrast, off-the-shelf modules. They are added to the building to complement the energy requirements set by the BPCA and, compared to the West façade, their aesthetic pursuit is negligible, highlighting the difficulty in making BIPV a constituent part of a comprehensive, all round design resolution.

\subsubsection{Tribeca Green, Millennium Tower, Site 23 and 24}

These buildings (see Figure 5) are designed at different intervals during the BPC development; they show, however, similarities in their design approach. Besides meeting the energy requirements, the PV panels serve at most the additional function of rain screen to the building's bulkhead, as in Tribeca Green and the Millennium Tower, or as rooftop trellises and on top of the bulkheads, in the Site 23 and 24 buildings.

Figure 5. PV in: (a) Tribeca Green; (b) Millenium Tower; (c) Site 23 and 24 [29].

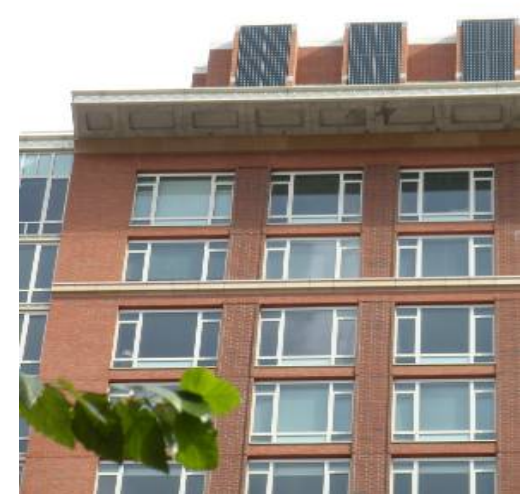

(a)

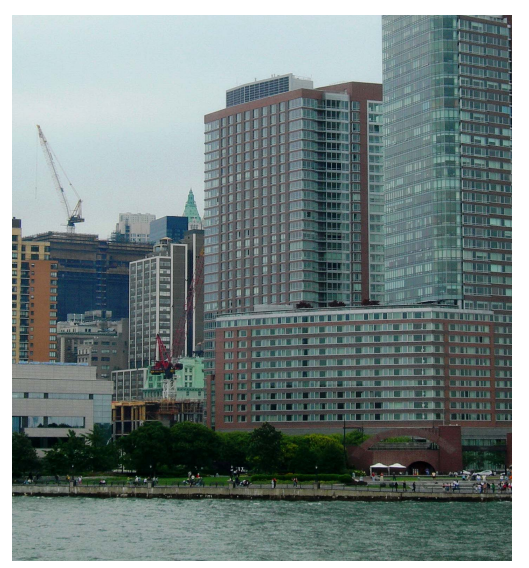

(b)

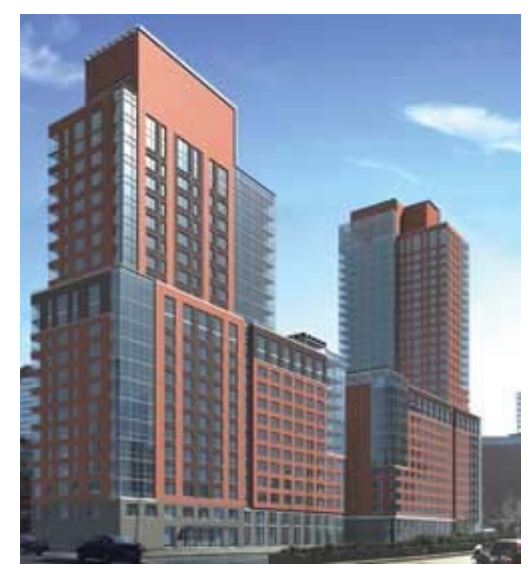

(c)

Considering that PV application needs to gain regulation approval and any proposal that goes beyond tested solutions may not be realized, the design approach to PV in the above buildings is non-risk taking. Once the energy requirements are met, and a satisfactory aesthetic solution is achieved, there is no further push towards finding innovative ways to include PV in the design process. Such approach is stressed in the Site 23 and 24 designs, where the architects ensure an effective 
application of PV by considering upfront what would meet the BPCA requirement and building regulation [22,23]. In the Millennium Tower, PV panels are placed on the roof top as a PV stand alone system, suggesting disengagement to the building's design composition process.

\subsubsection{The Verdesian}

In the Verdesian building (see Figure 4) the custom made PV panels cover primarily the East and West of the building's bulkhead. Besides generating energy, their additional constructional role is of rain screen for the mechanical rooms. It is important to note that the architects of this building insisted on maintaining the vertical mullion aesthetics on its West façade all the way to the building's bulkhead. The bulkhead's vents are, for that reason, located in the South façade, reducing the area of PV southern exposure and consequently the PV system energy potential; a design choice that shows the priority given to the aesthetic composition of the BIPV façade over its energy generating potential.

\subsubsection{The Visionaire}

The Visionaire's PV custom-made panels (see Figure 6) act as a full cladding system, incorporating a ventilated cavity to avoid heat build up and loss of PV efficiency. The panels represent an example of learn by doing, gathering from the Solaire's experience where the direct contact of the insulation to the PV glass generates heat build up, and incorporating the technological improvements in the building design process. In the Visionaire, the architects maintain the PV panels flush with the façade. In doing so, however, they rely on a fixed building configuration and show, as in the Solaire, the domestication of PV to an aesthetic and constructional role.

Figure 6. The Visionaire [30].

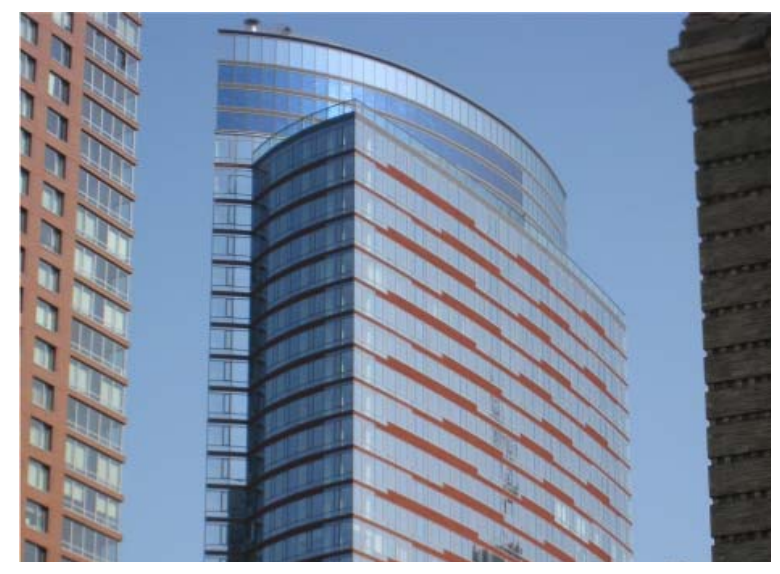

\subsubsection{The Riverhouse}

The Riverhouse (see Figures 7 and 8) is one of the last buildings to be completed at BPC and, perhaps because of that, one of the most innovative with PV application. The building's large volume and base building energy demands would have required vast PV surfaces. The architects responded to this requirement with a dynamic PV sunlight tracking system in the building's bulkhead, shown in Figure 8. The system crowns the building and is expected to allow up to $20 \%$ increase in efficiency when compared to an equivalent solution with fixed PV [22,23]. Here, the PV does not substitute any 
architectural building's component. This trade off, however, allows the PV to work freely and to deliver what is arguably PV primary function, to effectively generate energy from the sun.

Figure 7. The Riverhouse [28].

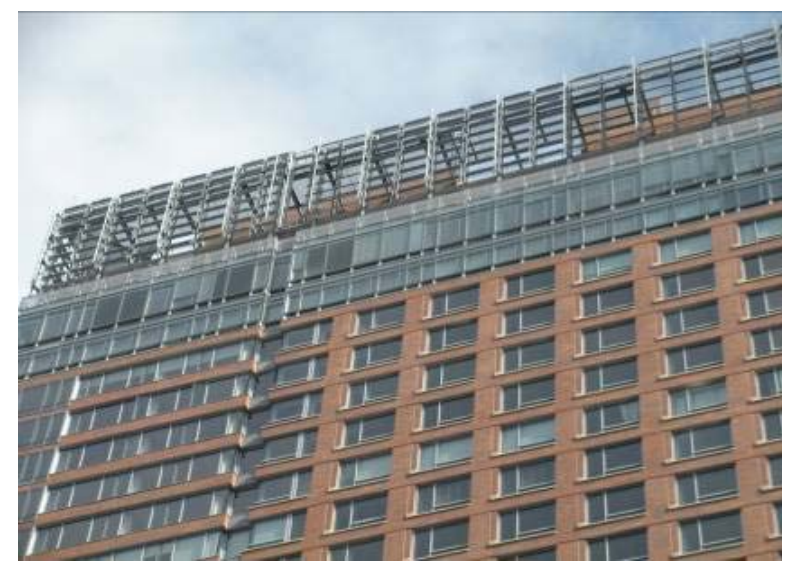

Figure 8. The Riverhouse dynamic PV system [28].

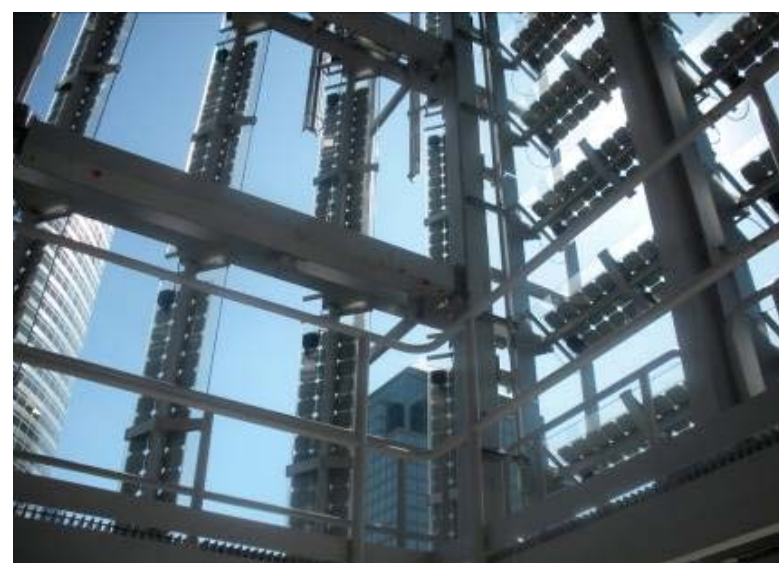

\subsection{PV Industry and the Design Process}

When the BPC architects and PV installers were asked about the single most important lesson learned on the application of PV in the design process, the recurring theme is that of the challenging relationship architects have with the PV industry, and the need for PV versatility [24-27]. That has obvious design implications as each solution has to be valuated by local jurisdictions, leaving the approval of each specific proposal of PV integration uncertain. In this sense, the IEA-PVPS Task 7 architectural criteria is perhaps a testimony of the need to find a common ground between what the PV industry can offer and the architects requirement of PV versatility. The confining BPC building program magnifies this issue, showing examples that range from high connection to disengagement of PV in the design process. This disengagement can be seen, for example, in the Millennium Towers, where the PV system is placed vertically on the building's rooftop detached from any significant contribution to the building's architectural design. In other cases, however, there is a strong will to find a common ground by integrating PV into the design process, such as in the Solaire's West façade. 


\subsubsection{The Case of the Solaire's West Façade}

The Solaire's West façade, shown in Figure 2, could be considered as the most important example at BPC of finding a meeting point between what the PV industry can offer as a product, and its integration into the buildings design process. The Solaire's designers were faced with a design challenge that was unprecedented for their office, which also meant dealing for the first time with trade issues on ownership over the installation of the custom made PV panels. The window installers, the iron worker, and the electrician called for ownership and responsibility over the panel's installation. The debacle was resolved by sending each PV customized panels to an offsite window manufacturer who glazed them into a unit. The panels were then delivered to site and installed by window glaziers as window elements and wired by electricians. This non-programmatic way of operating, in which the outcome shows to be the product of an empirical approach, suggests that we are still at a very early phase of PV integration in buildings. Architects and PV producers have to improvise to find solutions and the outcome of PV design integration is highly uncertain.

\subsubsection{PV and Glass}

Arguably, PV is an unlikely architectural component because it still lacks the versatility of most building elements necessary to compose architecture, such as, for example, a brick or a concrete masonry unit. The best way of PV becoming a versatile architectural component, as the architects and PV installer in this study suggest, is to associate PV with glass. The architects state that: "PV is basically glass, and is to be treated as such' [24], 'PV can potentially disappear' [25]. The PV installer suggests architects to 'consider PV as glass' [23] and that 'PV glass replaces standard glass' [31]. In fact, PV is treated at BPC either like an add-on glass panel (Tribeca Green, Site 23 and 24, and the Riverhouse) or like an extension of the building's glass envelope (Solaire, Verdesian, and Visionaire). Although the association glass-PV presents the apparently insurmountable challenge of allowing for transparency while absorbing light energy, many innovative PV producers are already going in this direction. This study suggests that the main advantage of PV as glass is that it would become an architectural component, rather than a system, greatly increasing its versatility in architecture, and hence its ability to be incorporated in the design process.

\subsubsection{Green Visible}

If a PV systems' main purpose is to generate energy from renewable sources and significantly contribute to a building's energy demands, then the PV installed at BPC need to be put into question. In fact, the BPCA 2000 Guidelines requirement to provide only 5\% of the base energy load, updated in 2004 to $0.75 \%$ of the building's base energy loads calculated on the actual PV energy produced, is a small contribution to a building's energy demands, particularly when compared to the estimated energy potential of BIPV. To put things in perspective, based on a IEA-PVPS report, it is estimated that if building surfaces are used that generate $80 \%$ of the maximum solar power, the ratio between BIPV solar electricity production and current electricity consumption can vary from $15 \%$ to almost $60 \%$ in IEA countries [13]. 
At BPC, the PV's purpose of rendering the buildings' green agenda visible to the public predominates. This intention is already present in the BPCA guidelines [20], which state: "Where appropriate, strongly consider using BIPV in locations that are highly visible to the public" (p.11). PV is evidently considered the primary tool for conveying the green message. This is reinforced by Kaplan, who describes PV "one of the few green elements that people see" [22], and by architect of record of the Riverhouse, Bhaskar Srivastava, who states that PV "has a pedagogical intent"[27], showing a clear wish to be less dependent on non-renewable energy sources. The BPC development, however, provides no single comprehensive visual design strategy. According to Kaplan, developers were required to integrate PV without aesthetically knowing what directions they wanted PV to take them [22]. The design approach in the BPC buildings is highly diversified: it goes from a full commitment to PV integration within a building's aesthetics, to simple PV labeling. These two extremes, and the variations in between, are discussed below.

\subsubsection{The Two Extremes: The Solaire and Millennium Towers}

In visual terms, the Solaire stands out as the most experimental and risk taking of the BPC buildings considered in this study. The visual engagement of PV starts at street level, with the embedment of PV cells in the entrance canopy, and continues upwards on West façade with the color variation of the recycled Intel chip cells. There is, in the Solaire, an attention to scale and visual perception. At street level one can see the single PV cells of the canopy, from further away the electric blue panels blend in the West facade. In the Millennium Tower, by contrast, the PV cell array is out of visual reach from the street. Being on the building's roof top and facing West towards the river, the Millennium tower PV system can only be spotted from an aerial view, as shown in Figure 5b. The design approach in the two buildings goes to the two extremes: fully committed to engage the public in the Solaire, satisfied with just confirming the PV energy requirements in the Millennium Tower.

\subsubsection{Variations to the Green Visible Theme}

The architect's push towards a green manifesto is well seen in the Visionaire building. Kaplan describes how, during the building's design development phase, the Visionaire's architect's wanted to change the PV color, from black to blue, and how this would have meant increasing the PV blue cells surface area (to obtain equivalent energy output). It is important to note that the architect, initially resisted to satisfying that revised surface requirement [22]. The event is significant, because it shows the designer's focus on the PV symbolic role over its energy goal. In the Visionaire, evidently, a symbolic PV blue strip flag sufficed to send the green message.

Tribeca Green, the Verdesian and Site 23 and 24 buildings all come under the BPC building typologies that have to rely on the bulkhead and rooftop of the building to guarantee sufficient PV exposure to sunlight. The Tribeca Green and Verdesian buildings are, however, the only ones that can count on a certain degree of visibility from the street level. It is perhaps because of this reason that the incorporation of PV in these two buildings is visually incisive. In both instances the PV stands out from the buildings fabric: jet black in Tribeca Green, electric blue in the bulkhead of the Verdesian, both against the buildings' red brick fabric. The PV of the two buildings must be noticed, even if that means in stark contrast with the buildings' fabric. 
In the Riverhouse there is no need to negotiate between PV and building's composition because the PV systems stand out for what they are: a mechanical device, detached from the building's main body. The only compositional license in the Riverhouse is the design of fake PV panels on the North façade to complete and crown the building. In the Riverhouse, there is no detachment between PV aesthetics and function. PV is expressed for what it can offer: a machine-like technology that generates energy.

\section{Conclusion Remarks}

The research analysis of the PV systems at BPC has led to a series of emerging themes. The content of these themes has led to findings that can be of use to a better understanding of the integration of PV in the architectural design process. These are:

\subsection{The "Carrot and Stick"}

Mandating PV in a building's design process can initially find resistance by architects and developers alike. There is evidence, however, that this can trigger a wider and more consistent application of PV in architecture. The application of PV in a rigid pre-constituted building program (such as the BPC development) limits the contribution of PV in a building's design resolution. The study suggests that greater design potential (ability of PV to contribute to a building's resolution) and greater scope (a more significant contribution to a building's energy demands) would allow a greater design involvement and push for innovation.

\subsection{PV and Building Integration}

The BPC buildings show that PV can assume three different roles: that of energy generators, as substitute to building component, and an aesthetic complement to the building's composition. In all of the BPC buildings, however, there is a distinct visible separation and prioritization of the roles (including in the Solaire where, to meet the pure energy goals, additional PV arrays have to be added on the roof bulkhead), showing the difficulty in integrating photovoltaic technology and architecture. Depending on the architect's design approach, PV verge towards aesthetic goals, their function as building components, or as efficient energy generators, but not all of these three things together. The study suggests that, with the current PV technology offered, by releasing one of the PV roles (i.e., that of substituting a building component) it allows PV to work more effectively. This satisfies what is arguably the PV imperative: to generate energy from the sun in the most efficient way possible.

\subsection{PV Industry and Design Process}

There is a consensus among the architects that the relationship between PV industry and architectural design is a difficult one. In design projects that explore the integration of PV in architecture and push for new solutions, that relationship is still improvised, and the outcome highly uncertain. This calls for a robust program that will ensure greater control over that relationship while allowing for innovation to take place. PV versatility is key in PV building integration and this can be pursued with PV as a building element. Architects are already associating PV with glazing, suggesting that this is where the technological efforts need to be placed in the evolution of BIPV. 


\subsection{Green Visible}

Together with wind turbines, PV is a commonly recognizable form of renewable energy generation system. This is an attractive incentive for architects and developers that want to convey a message of green involvement to the public. The PV's overwhelming ability to send the green message with little corresponding substance in energy provision can, however, distract from PV's primary function of generating energy.

Overall, the findings of the research suggest that the integration of PV technology in architecture is still at a raw and early phase, and that PV integration as an organic, constituent part of the design process may require a significant leap in PV technology. Battery Park City is perhaps an expression of the short-term goals of PV design integration. These are: to promote PV in the building industry, to build knowledge on the integration PV in the design process, and to render PV green technology visible. A long-term goal of PV integration in sustainable architecture, however, must have as primary imperative to make PV generate energy efficiently, and significantly contribute to a building's energy demands.

\section{Acknowledgements}

The author of this paper would like to thank the BPCA and all of the architects cited in the text. A particular thanks to Susan Kaplan, who made this study possible in the first place, and to Anthony Pereira for his sustained support. Many thanks also to my colleague, Timothy O. Odeyale, for his precious suggestions in writing the paper.

\section{References}

1. Thomas, R. Photovoltaic in Architecture; Spoon Press: New York, NY, USA, 2001.

2. Prasad, D.; Snow, M. Designing with Solar Power; The Images Publishing Group PTY Ltd.: Melbourne, Australia, 2006.

3. Weller, B.; Hemmerle, C.; Jakubetz, S.; Unnewehr, S. Detail Practice: Photovoltaic; Birkhauser: Basel, Switzerland, 2010.

4. Krawietz, S. Building Integration of Photovoltaics: A Guideline for Practical Use; Springer: London, UK, 2011.

5. German Solar Energy Society (DGS). Planning and Installing Photovoltaic Systems: A Guide for Installers, Architects and Engineers; Earthscan: London, UK, 2012.

6. International Energy Agency Photovoltaic Power System (IEA-PVPS). IEA-PVPS Annual Report (2008-2011); IEA-PVPS: Fribourg, Switzerland, 2012. Available online: http://www.ieapvps.org/index.php?id $=6$ (accessed on 27 November 2012).

7. IEA-PVPS. IEA-PVPS Trends in Photovoltaic Applications: Survey Report of Selected IEA Countries between 1992 and 2011; IEA-PVPS: Fribourg, Switzerland, 2012. Available online: http://www.iea-pvps.org/index.php?id=32 (accessed on 27 November 2012).

8. Oliver, M.; Jackson, T. Energy and economic evaluation of building-integrated photovoltaics. Energy 2001, 26, 431-439. 
9. Kasahara, T.; Plastow, J. Added Values of Photovoltaic Power Systems. In Proceedings of 3rd World Conference on Photovoltaic Energy Conversion, Osaka, Japan, 11-18 May 2003.

10. IEA-PVPS. IEA-PVPS Potential for Building Integrated Photovoltaic, 2002; IEA-PVPS: Fribourg, Switzerland, 2002. Available online: http://www.iea-pvps.org/index.php?id=9\&tx_ damfetools_pi1[setCatList] $=61-78$ (accessed on 27 November 2012).

11. Marsh, G. BIPV: Innovation puts spotlight on solar. Renewable Energy Focus 2008, 9, 62-67.

12. IEA-PVPS. IEA-PVPS Task 7. Photovoltaic Power Systems in the Built Environment. Available online: http://www.iea-pvps.org/index.php?id=53\&no_cache=1\&sword_list[]=integration (accessed on 27 November 2012).

13. Schoen, T.; Prasad, D.; Ruoss, D.; Eiffert, P.; Sørensen, H. Task 7 of the IEA PV Power Systems Program-Achievements and Outlook. In Proceedings of the 17th European Photovoltaic Solar Energy Conference, Munich, Germany, 22-26 October 2001.

14. IEA-PVPS. IEA-PVPS Task 10. Urban Scale Photovoltaic Applications. Available online: http://www.iea-pvps.org/index.php?id=46\&no_cache=1\&sword_list[]=integration (accessed on 27 November 2012).

15. Gaiddin, B.; Kaan, H.; Munro, D. Photovoltaics in the Urban Environment; Earthscan: London, UK, 2009.

16. Kaan, H.; Reijenga, T. Photovoltaic in an architectural context. Prog. Photovolt. Res. Appl. 2004, 12, 395-408.

17. Bahaj, A.S.; James, M.F.; Jentsch, M.F. Photovoltaics: Added value of architectural integration. Proc. ICE Energy 2007, 160, 59-69.

18. Kaplan, S. Battery Park City Authority, New York, NY, USA. Personal communication, 2007. Available online: http://eprints.lincoln.ac.uk/2583/ (accessed on 27 April 2013).

19. Battery Park City Authority (BPCA) Homepage. Available online: http://www.batteryparkcity.org/ (accessed on 20 April 2013).

20. BPCA. Hugh L. Carey Battery Park City Authority Residential Environmental Guidelines; BPCA: New York, NY, USA, 2005.

21. U.S. Green Building Council (USGBC). LEED Green Building Rating Systems. Available online: http://www.usgbc.org/DisplayPage.aspx?CMSPageID=222 (accessed on 27 November 2012).

22. Kaplan, S. Battery Park City Authority, New York, NY, USA. Personal communication, 2009. Available online: http://eprints.lincoln.ac.uk/2583/ (accessed on 27 April 2013).

23. Pereira, A. AltPower, New York, NY, USA. Personal communication, 2009. Available online: http://eprints.lincoln.ac.uk/2583/ (accessed on 27 April 2013).

24. Hess, D. Pelli Clarke Pelli Architects, New York, NY, USA. Personal communication, 2009. Available online: http://eprints.lincoln.ac.uk/2583/ (accessed on 27 April 2013).

25. Kearns, R. Handel Architects, New York, NY, USA. Personal communication, 2009. Available online: http://eprints.lincoln.ac.uk/2583/ (accessed on 27 April 2013).

26. McCormack, B. EE\&K Architects, New York, NY, USA. Personal communication, 2009. Available online: http://eprints.lincoln.ac.uk/2583/ (accessed on 27 April 2013).

27. Srivastava, B. Ismael Leyva Architects, New York, NY, USA. Personal communication, 2009. Available online: http://eprints.lincoln.ac.uk/2583/ (accessed on 27 April 2013). 
28. Medio, S. Photovoltaic Design Integration at Battery Park City, New York. In Proceedings of Sustainable Architecture and Urban Development Conference (SAUDI 2010), Amman, Jordan, 12-14 July 2010. Available online: http://eprints.lincoln.ac.uk/3077/ (accessed on 20 April 2013).

29. Perkins Eastman and Ehrenkrantz Eckstut \& Kuhn Architects (EE\&K) Homepage. Available online: http://www.eekarchitects.com/portfolio/16-residential/9-liberty-green-and-liberty-luxe (accessed on 20 April 2013).

30. AltPower Homepage. Available online: http://www.altpower.com/home.php (accessed on 23 April 2013).

31. Allbee, A. AltPower, New York, NY, USA. Personal communication, 2009. Available online: http://eprints.lincoln.ac.uk/2583/ (accessed on 27 April 2013).

(C) 2013 by the authors; licensee MDPI, Basel, Switzerland. This article is an open access article distributed under the terms and conditions of the Creative Commons Attribution license (http://creativecommons.org/licenses/by/3.0/). 